\title{
配電線運転状態モニタリングシステムの開発

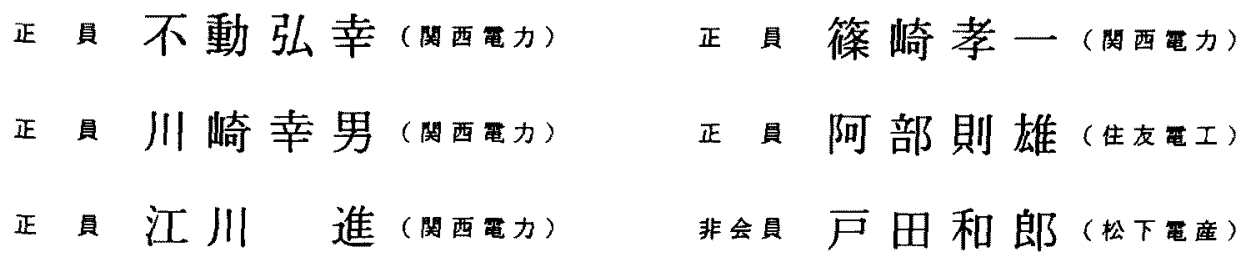

Development of a Distribution Line State Monitoring System

\begin{abstract}
Hiroyuki Fudou, Member, Yukio Kawasaki, Member. Susumu Egawa, Member, Kouichi Shinozaki, Member (Kanasa i Electric PowerCo., Inc.). Norio Abe, Member(Sumi tomo Electric Industries, Ltd), kazuro Toda, NonMember, (Matsusita Electric Industrial Co., Ltd.)
\end{abstract}

In order to improve the reliability of electricity service, a distribution line state monitoring system has been developed, which is composed of the central control unit, the remote control switches, the slave unit and the monitoring sensors. The first system employed fiber-optic voltage and current sensor. The latest system employs a unique form of cost reduction, with no voltage sensors incorporated. This system can detect the grounding direction by the information of the phase difference between the line-to-line voltage and $I_{0}$ provided by the monitoring sensor, and grounded line information(64 $\left.\phi\right)$ from the substation. The installation of the system has been proceeding since 1992, at present, displays its performance.

キーワード : 配電自動化，配電線自動運用，モニタリング，光センサ，開閉器子局

\section{1. まえがき}

配電線の供給信頼度を示す指標のうち，事故件数は開閉 器のオイルレス化，電線の絶縁化，耐雷設備の強化などで 近年著しく減少しており(1)，事故停電時間屯開閉器遠隔 制御システムの導入で減少傾向を示している(2)。

しかし，この開閉器遠隔制御システムでは配電線事故時 の区間特定までを従来の時限順送式によっているため, 1 配電線の分割可能区間は 8 区間となっている。

このため，郡部配電線のように区間こう長の長い場合に

は，事故点の探査に時間を要し長時間停電を招いていた。

そこで，この解決を図る要素技術として光方式電流セン サ(3) を用いた配電線運転状態モニタリング・センサを開 発した。この配電線運転状態モニタリング・センサを配電 線の 1 区間当たり 2 組以上設置し, 開閉器遠隔制御システ ムと組み合わせることにより，事故区間を従来の $1 / 2$ 以 下にできる配電線運転状態モニタリングシステムとして完 成させた。

システムの開発の結果，事故停電時間の短縮に寄与する とともに, 従来不可能であった再閉路成功事故の原因区間 特定をむ可能とした。

本論文では，これらの要素・システム技術を中心に報告 する。

\section{2. 配奄線荲転状態モニタリング・センサの開発}

センサ部は，図1のように配電自動化開閉器施設柱の高 压各相に設置し，配電線の電圧・電流を検出させるもので ある。

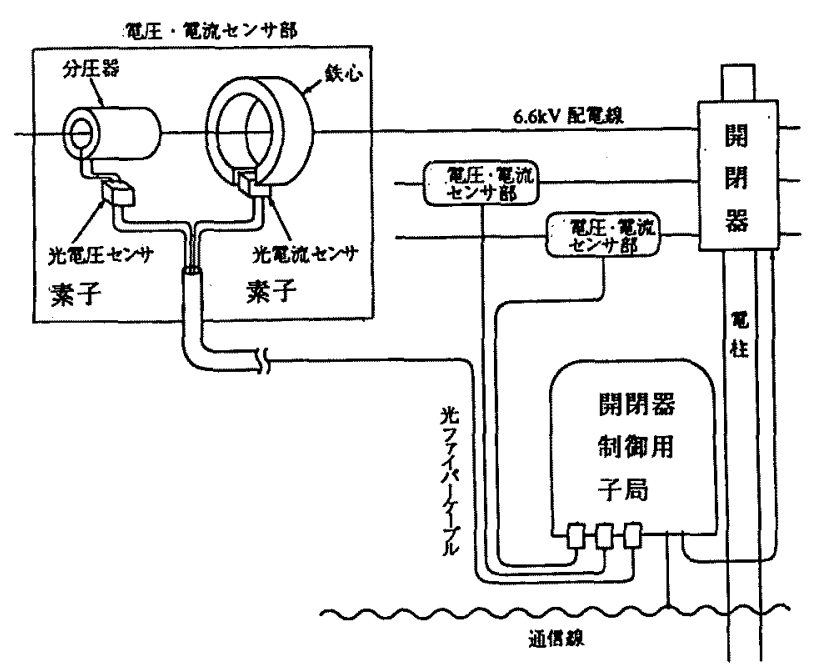

図 1 電圧および電流センサの構成

Fig. 1. Construction of the fiber optic voltage and current sensor system. 


\section{〈2. 1〉 電圧センサ部 ${ }^{(4)}$}

電圧センサ部は絶縁電線の絶縁信頼度を低下させないよ う図 2 のように非接地とし, 電線・大地間の電位差を 2 枚 の電極で分生したコンデンサ分圧器と対地浮遊静電容量に より分担電压 $V_{s}$ をポッケルス素子（B SO）で湘定して いる。なお, 分担電压V $\mathrm{s}$ は次式で表される。

$$
\mathrm{V}_{\mathrm{s}}=\left(\mathrm{E} / \mathrm{C}_{2}\right) / \sum_{\mathrm{i}=1}^{3}\left(1 / \mathrm{C}_{\mathrm{i}}\right)
$$

分担電圧を約 $200 \mathrm{~V}$ 設計としており，対地浮遊静電容 量 $\mathrm{C}_{3}$ は $1 \mathrm{pF}$ 程度であり, $\mathrm{C}_{1} \fallingdotseq 20 \mathrm{pF}, \mathrm{C}_{2} \leftrightharpoons 20$ p Fのコンデンサ分珐器とした。

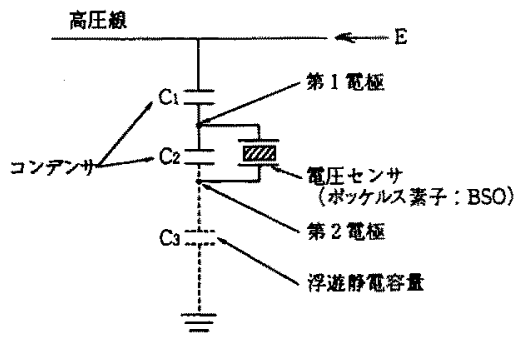

図2 電纴センサの分圧電圧

Fig. 2. Principle of voltage divider.

センサ部は，設置の容易性から 2 分割構造で，電線を挟 み込む形状とし，また，ポリエチレン樹脂ヶースに収納し 樹脂充填により気密構造としている。この構造では分王電 極の第 2 電極電位は固定されたものでなく，ケース表面の 污損・積雪・降雨時の表面抵抗低下に上り分担電圧低下を 招くことが想定される。そこで図 3 に示すセンサ設置状態 での等価回路でシミュレーションにより検討した。

降雨時にはセンサケース表面に付着した水が導電層を形 成するのでRs（センサ表面の抵抗）， $\mathrm{R}_{\mathrm{w}}$ （絶縁電線表 面の抵抗），Rws（絶縁電線表面一七ンサ表面間の抵抗） が变化する。この場合に分王電極に誘起される電圧振幅と 位相差の変化のシミュレーション結果は図 4 のようになる。
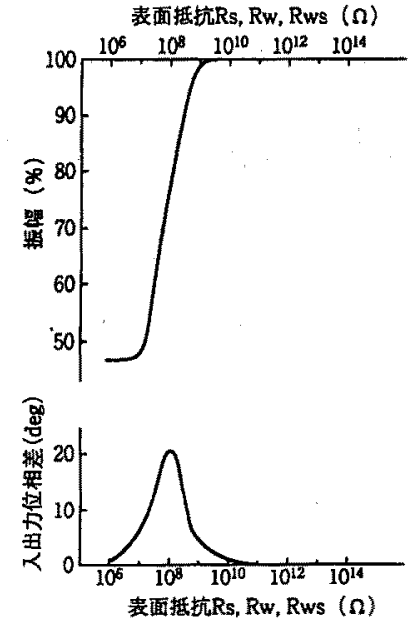

图 4 表面抵抗 $R_{s} ， R_{w} ， R_{w s}$ と出力電圧・位相の関係 (シミュレーション結果)

Fig. 4. Amplitude and phase of voltage sensor output vs. surface electrical resistance $R_{s}, R_{w}$, $R_{w s}$ of voltage sensor. (calculated values)

すなわち，表面抵抗が $10^{10} \sim 10^{3} \Omega$ から振幅の低下 が見られ，振幅は $10^{7}$ 凡以下では $1 / 2$ 以下となる。位 相差は $10^{8} \Omega$ 程度で変化が最大となり約 $20^{\circ}$ となる。

次に，光ケープル部とセンサ部表面とが需れ，それぞれ の水膜がつながった場合，つまり Rs（センサ表面の抵抗） $\mathrm{R}_{\mathrm{c}}$ （光ケーブル表面の抵抗），Rcs（光ケーブル表面 一センサ表面間の抵抗）が変化したときの分生電極に誘起 される電圧振幅と位相差の変化のシミュレーション計算結 果は図5のようになる。

すなわち，振幅および位相差が変化し始める抵抗值は図 4 の場合と同様であるが，電压掁幅の変化は $10^{7} \Omega$ 贝下 では乾燥時の 5 倍以上, 位相差の変化は $10^{8} \Omega$ 程度で約 $40^{\circ}$ にもなる。

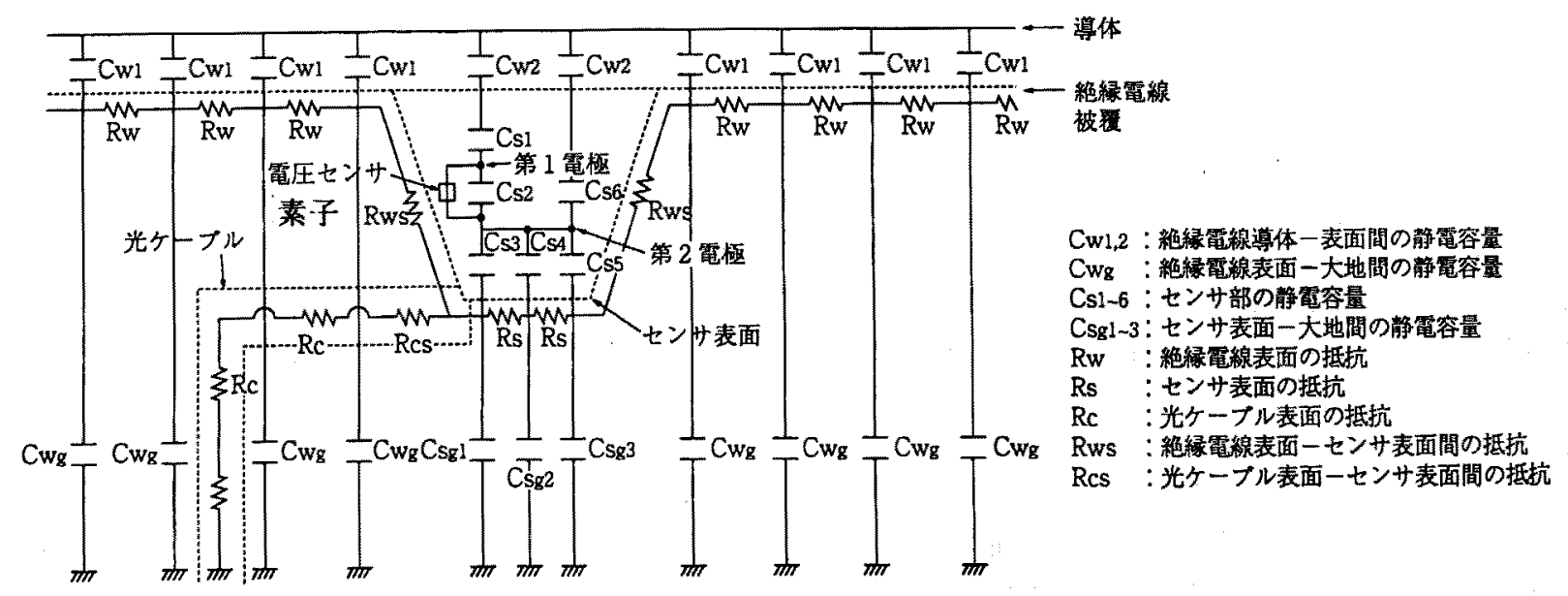

図 3 センサ設置状態での等価回路

Fig. 3. Bquivalent circuit of vollage sensor on distribution line. 


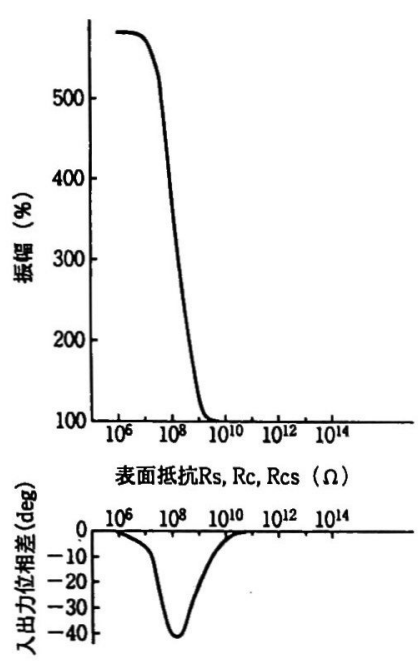

図 5 表面抵抗 $R_{s} ， R_{c} ， R_{c s}$ と出力電圧・位相の関係 (シミュレーション結果)

Fig. 5. Amplitude and phase of vol tage sensor output vs. surface electrical resistance $R_{s}, R_{c}$, $R_{c s}$ of voltage sensor. (calculated values)

このため，本センサでは図 6 のようにセンサの両端と光 ケーブル部に水切り部を設けて, $\mathrm{R}_{\mathrm{ws}}$ と $\mathrm{R}_{\mathrm{cs}}$ を十分大きく する対策を実施している。この対策により，センサ出力変 動が $20 \%$ 程度の変化から, 地絡事故検出に支障ない程度 （数\%）に抑制できることを実験により確認している。

電压センサでの計測データは, 光ファイバケーブルで電 柱下部の光信号処理部へ伝送し, テータ処理させている。

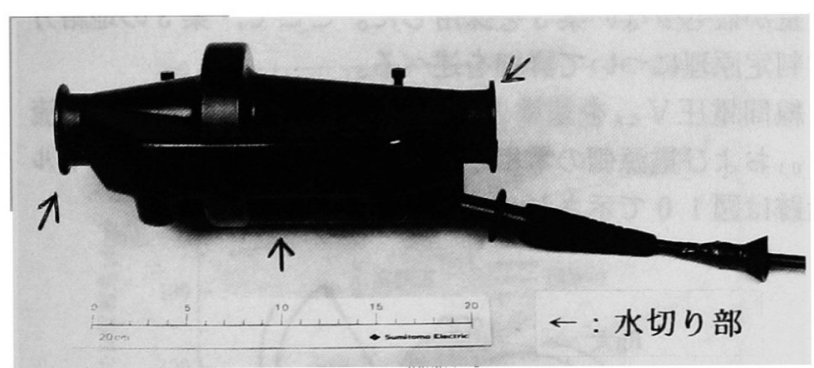

図 6 センサ部の外観

Fig. 6. Appearance of sensor.

\section{〈2.2〉流センサ部 (s)}

電流センサ部は, 導体部の通過電流による発生磁界をギ †ップ付き環状鉄心により収束し，ギャップ部に配置した ファラデー素子により電流検出する方式とした。この電流 センサ部は図 6 の電圧センサ部と一体化構造としている。

従来のファラデー素子では, 地絡電流が検出可能な高感 度, 日射や通電電流に起因する温度による感度変化の極小 化が期待できないことから，希士類鉄ガーネット結晶（B $\left.\mathrm{i}_{1.3} \mathrm{Gd}_{0.43} \mathrm{Y}_{1.27} \mathrm{Fe}_{5} \mathrm{O}_{12}\right)$ による新しいファラ テー素子を開発した ${ }^{(3)}$ 。これにより，感度は $5.0^{\circ} /$ $(\mathrm{O} e \cdot \mathrm{cm})$ となり, 感度変化は図 7 のように-2 0〜 $+80^{\circ} \mathrm{C}$ の温度範囲で士0. 5 \%内に抑制できるようにな
った。

電流センサでの電流計測データは, 光ファイバケーブル を介して電柱下部の光信号処理部へ伝送し、デー夕処理さ せている。

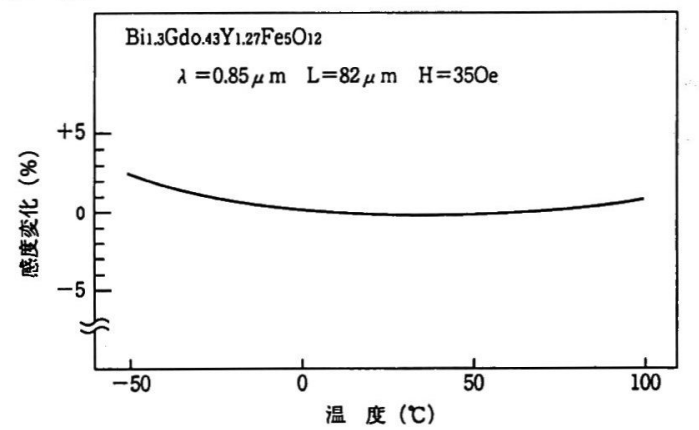

図 7 希士類鉄ガーネット結晶の感度の温度変化 Fig. 7. Temperature variation of sensitivity of the Bi-substituted rare-earth iron garnets.

\section{3. 事故検出原理}

〈3.1〉莞圧・是流センサを利用した事故検出

本方式は, 各相の電圧検出と各相の電流検出を行ない, 開閉器制御用子局内の信号処理回路で電気信号に変換した のち三相合成してV。，I。を算出し，地絡検出およびそ の他の事故検出を行なう方式である。

また，本方式での検出性能は表 1 のとおりであり，信号 処理のブロック図を図 8 に示す。

表 1 検出性能

Table. 1. Characteristics of detecting.

\begin{tabular}{|c|c|}
\hline 分 & 検 出 \\
\hline 負荷電流計谢 & 0５10A（線路定格電流 $400 \mathrm{~A} ）$ \\
\hline 地 絡 検出 & 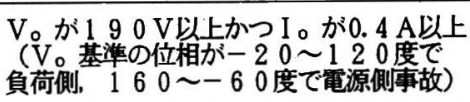 \\
\hline 過電流検出 & 480 A以上かつ $100 \mathrm{~m} \mathrm{~s}$ 以上 \\
\hline 断線欠相検出 & $\begin{array}{l}\text { V。が } 190 \text { V以上かつ } 1 \text { 相電流の低下が } \\
37.5 \% \text { 上上 }\end{array}$ \\
\hline
\end{tabular}

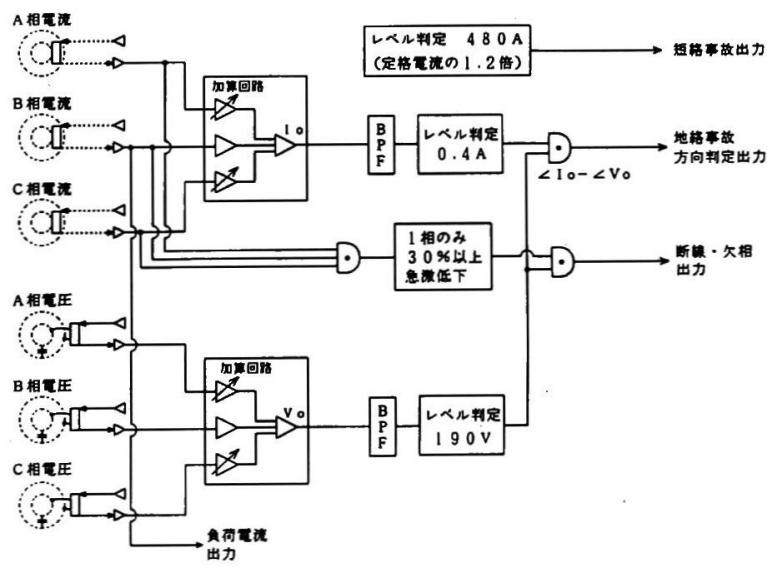

図 8 信号処理ブロック図

Fig. 8. Block diagram of signal processor. 
a. 地絡事故検出

信号処理回路で算出されたV。，I。を基に従来の判定 方式で地絡事故検出を行っているが, 絶縁電線へのセンサ 取り付け状態のばらつきなどによる残留成分除去のためD / A コンバータによるゲイン調整回路を付加している。

この結果得られたVo，I。のきさと位相角から地絡 事故の有無および地絡方向判別（センサ取り付け点の負荷 側, 電源側の区分）をさせている。

b. 過電流 (短絡事故) 検出

電流センサでの各相計測電流値のいずれかが, 設定值超 過の場合を過電流と認識させている。

C. 断線・次相事故検出

断線・欠相が発生した地点より負荷側ではV。が現れ, 負荷電流も低下するのでV。の大きさと負荷電流の変化率 から発生を検出している。

\section{〈3. 2〉電流センサのみを利用した事故検出}

前述の<3． $1>$ 項の事故検出方式は，フィールド試験 でも十分な実用性を検証できたが，さらに，コスト面から の見直しを図った結果, 光電圧センサを用いない事故検出 方式を開発した。電流センサのみを利用する方式では, 図 6 のセンサ部から電圧センサ部およびコンデンサ分圧器を 取り除いたもので図 9 のようなセンサとした。

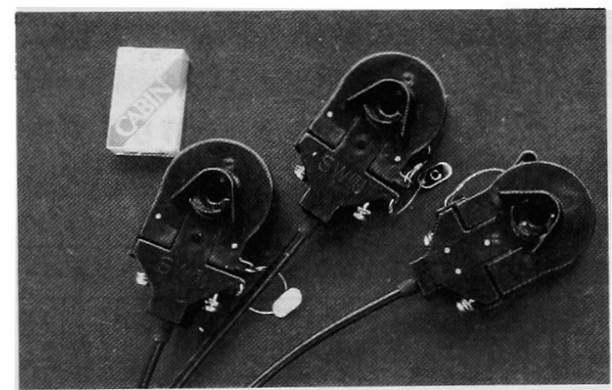

図 9 電流センサの外観 (三相分)

Fig. 9. Appearance of current sensor.

\section{a. 地絡事故検出}

配電自動化開閉器施設柱では, 開閉器の制御電源として A C 相電圧を利用している。そこで, この信号と電流計湘 信号を処理して地絡検出と地絡方向判定ができる新方式を 考案し，表 2 の 3 種類について検討した ${ }^{(6)}$ 。

案 1 は, 変電所と開閉器制御用子局（以下，子局という） とで共通の線間電压 $V_{1} （ V_{\mathrm{CA}}$ 相当）を基準とし, 変電所 で計測したV。とV $V_{1}$ との位相差 $\theta_{1}$ と, 子局で計測した $I_{0}$ とV $V_{1}$ との位相差 $\theta_{2}$ を, 配電自動化伝送路を通じて 中央装置に集め, $\left(\theta_{2}-\theta_{1}\right)$ を演算し地絡方向判定を 行うものである。

案 2 は, 案 1 とは逆に変電所で計測した $\theta_{1}$ を配電自動 化伝送路を通じて子局へ伝送し, 子局で $\left(\theta_{2}-\theta_{1}\right)$ を 演算して地絡方向判定を行うものである。

案 3 は, 変電所で検出した地絡相と子局で計測した $\theta_{2}$

\section{表 2 地絡検出方式の比較}

Table.2. Comparison of block schematic diagrams of detecting ground faults.

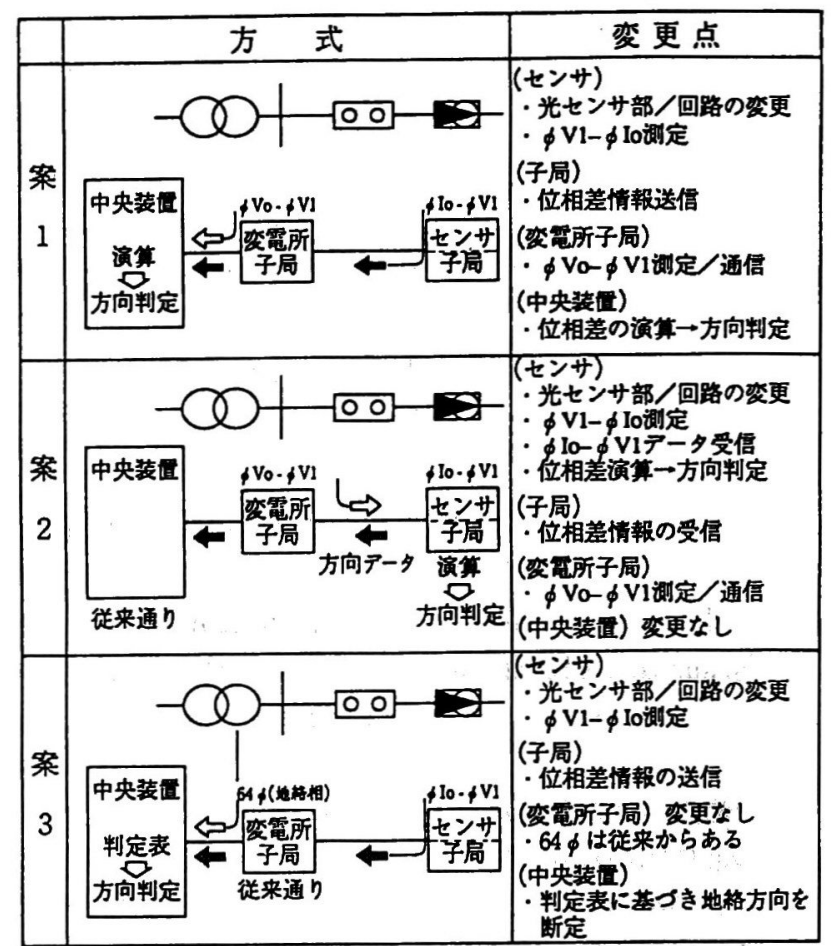

を配電自動化伝送路を通じて中央装置に集め地絡方向判定 を行うものである。

これらを比較して既導入の開閉器遠隔制御システムの変 更量が最も少ない案 3 を採用した。ここで, 案 3 の地絡方 向判定原理について詳細を述べる。

線間電圧 $V_{\text {cA }}$ を基準とした地絡点の負荷側の零相電流 $I_{01}$ および電源側の零相電流 $I_{02}$ の 1 線地絡時のベクトル 軌跡は図 10 で示される。

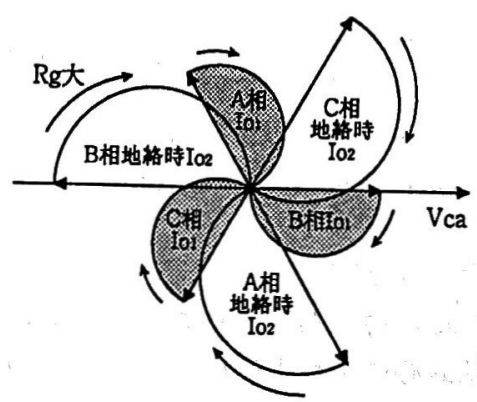

図 $10 \mathrm{~V}_{\mathrm{CA}}$ 基準の I $\mathrm{O}_{1}$ および $\mathrm{I}_{{ }_{02}}$ のベクトル軌跡 Fig. 10. Vector orbits of $I_{01}$ and $I_{02}$ on grounding.

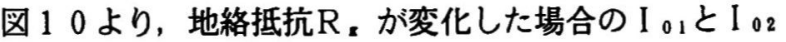
の変化領域には重なりがあり，I。のみでは地絡方向判定 ができない。しかし，64申 (地絡相判別継電器) で地絡 相が特定できると図 11 のように地絡方向判定領域の分離 が可能となる。 
この考え方を検証するため, 図 12 に示す人工地絡試験 装置で水の抵抗值で模擬した $\mathrm{R}$ ：を変え，線路模撽容量を 2. $188 \mu \mathrm{F}$ (完全地絡時の 1 線地絡電流約 $3 \mathrm{~A}$ 相当: 周波数 $60 \mathrm{~Hz}$ ）として地絡実験を実施した。

実験結果は図 13 に示すとおりで，横軸は地絡抵抗の代 わりに零相電圧 $V_{0}$ 。で表しており，理論值とよく一致する

ことから新しい方向判定手法の実現性が確認できた。

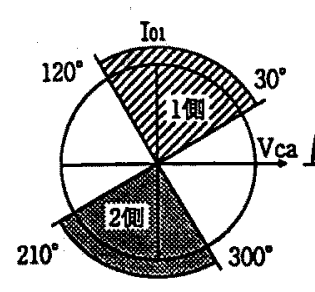

I02

A相地結特

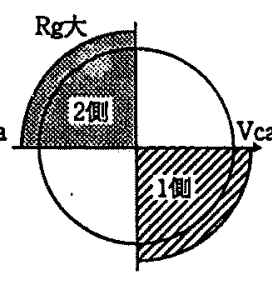

B相地絡時

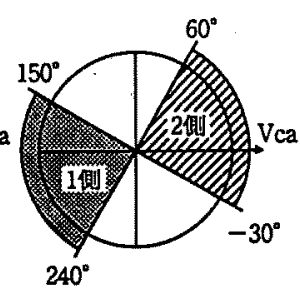

C相地辂時
（1僋：更源側地絡、2僋：負荷側地絡）

図 11 地絡相別の地絡方向判定

Fig. 11. I o vector of each phase on grounding.

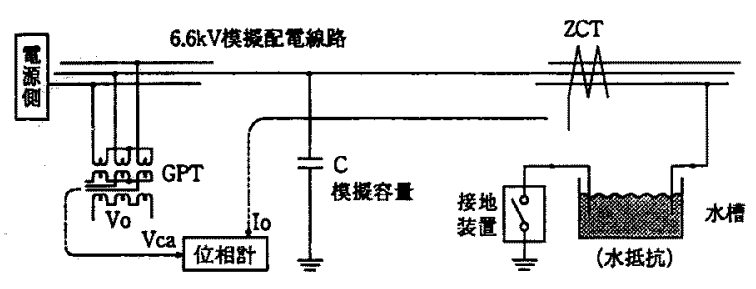

図 12 人工地絡試験装置

Fig. 12. Equipment for artificial grounding test.

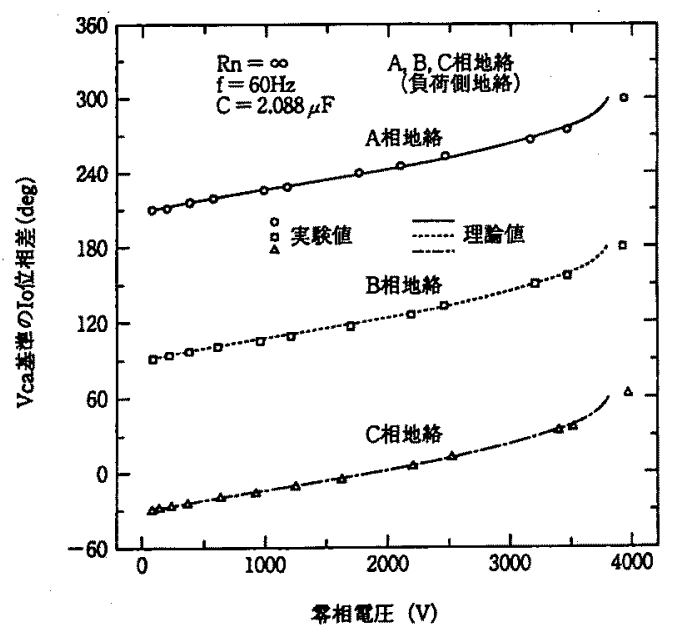

図 13 零相電圧と $\left(I_{0}-V_{C A}\right)$ の位相差

Fig. 13. Zero-phase voltage vs. phase difference of $I_{0}$ to $V_{C A}$

この結果を受け，位相差測定は方向誤判定のない範囲で 実施できればよいことを考虑し $360^{\circ}$ を $22.5^{\circ}$ 刻み で1 6 分割し, 表 3 のように処理ビッ卜数を最小化した地 絡方向判定テーブルを作って中央装置で処理させている。
表 3 中央装置での地絡方向判定テーブル Table. 3. Grounding direction determination table.

\begin{tabular}{|c|c|c|c|}
\hline 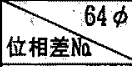 & A 相地絡 & B 相地絡 & C 相地絡 \\
\hline 0 & \multirow{7}{*}{$\begin{array}{l}1 \text { 側地絡 } \\
\text { (館源側) }\end{array}$} & \multirow{2}{*}{1 側地絡 } & \multirow{4}{*}{2 側地絡 } \\
\hline 1 & & & \\
\hline 2 & & 不感且 & \\
\hline 3 & & \multirow{7}{*}{2 側地絡 } & \\
\hline 4 & & & 不感帯 \\
\hline 5 & & & \multirow{7}{*}{1 側地絡． } \\
\hline 6 & & & \\
\hline 7 & 不感帯 & & \\
\hline 8 & \multirow{7}{*}{$\begin{array}{l}2 \text { 側地絡 } \\
\text { （負荷側） }\end{array}$} & & \\
\hline 9 & & & \\
\hline 10 & & 不感带 & \\
\hline 11 & & \multirow{5}{*}{1 側地絡 } & \\
\hline 12 & & & 不感帯 \\
\hline 13 & & & \multirow{3}{*}{2 側地絡 } \\
\hline 14 & & & \\
\hline 15 & 不憵带 & & \\
\hline
\end{tabular}

b，過電流（短絡事故）検出

< 3.1 > 項の事故検出方式と同一の検出条件としてい る。

c. 断線 - 久相事故検出

負荷電流の $80 \%$ 以上の急激な低下, 電源電圧の $80 \mathrm{~V}$ 以下の低下, 負荷電流低下相以外の 2 相が逆位相のAND 条件を断線・欠相の検出条件としている。

これらの事故検出処理を行う信号処理回路は，図14の 信号処理ブロック図とした。

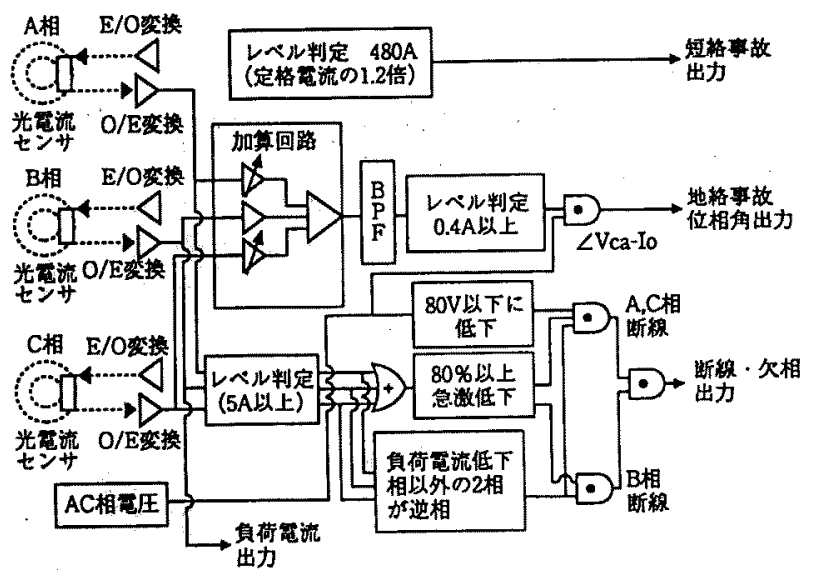

図 14 信号処理ブロック図

Fig. 14. Block diagram of signal processor.

\section{4. 子局の檋成・機能}

3 項で述べた $2 つ の$ 事故検出方式のうち，コスト面から 電流センサのみを利用した検出方式を採用した。子局は図 15 の構成とし，従来の子局の構成に次の部分を付加して いる。

(1) 子局 C P U部と光信号処理部とのインターフェイス

(2) 配電線停電時の電源バックアップ機能部

以下, 配電線停電時の電源バックアップ機能について述 べる。事故区間の検出のためには配電線停電時に子局での 
検出情報を配電自動化用伝送路を通じて中央装置に送出す る必要がある。このため，子局には配電線停電時に検出情 報を送出するためのバックアップ電源の設置が必須となる。

配電自動化の伝送路方式には，伝送路に同軸・ペアケー ブルを使用する通信線方式と電力線そのものに信号注入す る配電線搬送方式とがあり，各々の場合について以下に示 すとおり異なるバックアップ方式を採用した。

a . 通信線方式の場合

バックアップ電源として，子局消費電流 $420 \mathrm{~mA}$ ，通 信時間 $90 \mathrm{~s} /$ 回, 通信回数 100 回, 充電回路不要の要 求条件を満足する二酸化マンガンリチウム電池を採用して いる。取換え頻度を考虑した場合，寿命 10 年以上のメン テナンスフリーの条件が必要となる。

図 16 は，二酸化マンガンリチウム電池について -20 ${ }^{\circ} \mathrm{C}$ 過酷条件下で定温保存試験を実施した結果を示すもの である。これから 10 年間の劣化を推定すると 65 サイク ルとなり，残存容量から見て必要なバックアップ回数 100 回に対し 2 倍以上の安全率があり上記選定電池で問 題ないことになる。

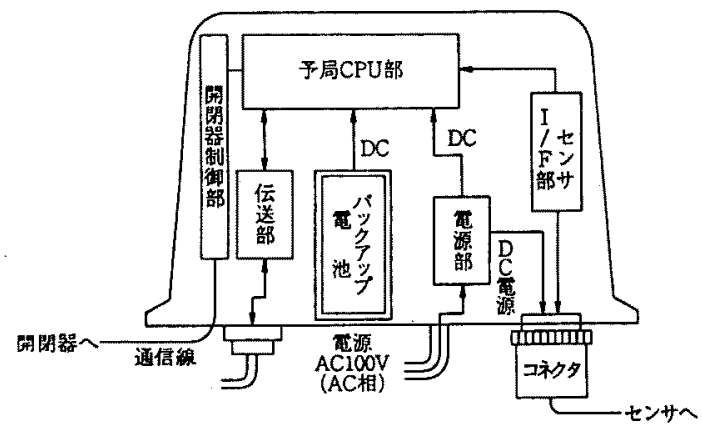

図 15 子局部の構成

Fig. 15. Construction of slave unit.

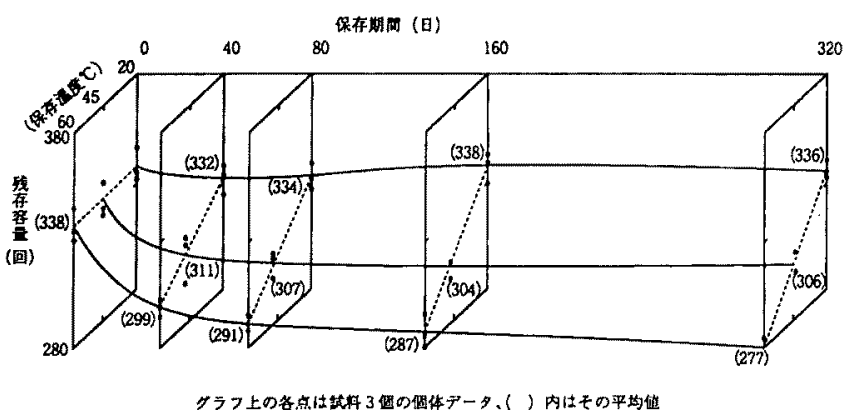

図 16 二酸化マンガンリチウム電池の定温保存試験 による保存期間之通信可能回数

Fig. 16. Retained capacity (the number of times of communication)vs. storage temperature and period for $\mathrm{Li} / \mathrm{MnO}_{2}$ batteries.

\section{b. 配電線搬送方式の場合}

配電線搬送方式では，配電線事故などの停電中は線路途 中の開閉器が無電圧開放機能により開放されるため中央装
置までの信号伝送路が断たれてしまう。しかし，隣り合う 子局同士は伝送路断とならないため通信が可能である。

そこで，本方式の場合は停電中に中央装置まで通信する のではなく，事故情報を持つ子局が自局より電源側にある 開閉器の子局まで送信し，再送電時に電源側開閉器の電源 が碓保された時点で検出情報を電源側開閉器の子局からそ の情報を中央装置に伝達するシステムとした。

このため，通信時間およびマーシンを含め 5 秒間のバッ クアップとし，必要容量のコンデンサを子局に内蔵させる バック方式(7) とした。

\section{5. システム全体の模成・機能}

配電線運転状態モニタリングシステム全体の構成は図 17 に示すとおり中央装置（営業所C P U ）, 変電所子局, 伝送路，子局，電流センサよりなっている。

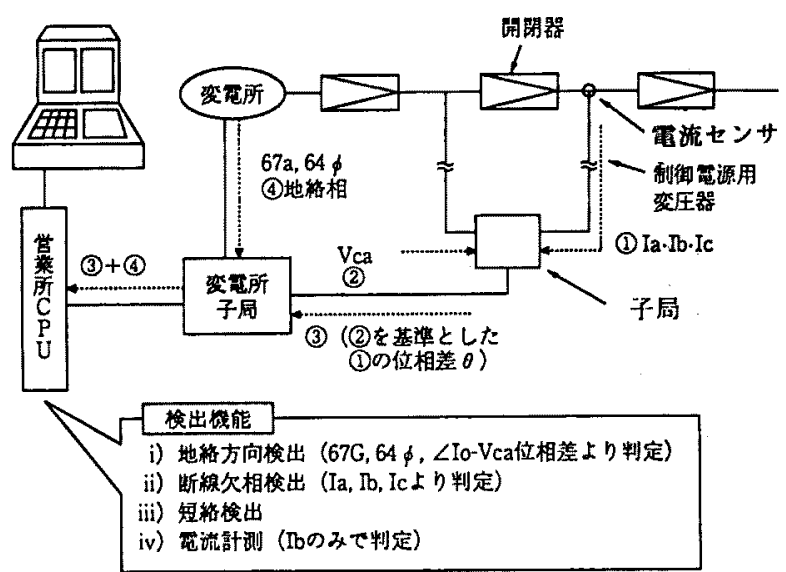

図 17 配電線運転状態モニタリングシステム全体の構成 Fig. 17. Configuration of a Distribution Line State Monitoring System

伝送路が同軸・ペアケーブルの場合について，地絡事故 時を例に，システム全体の動作を示すと次のようになる。

1）電流センサ部は正常時には各相の電流を計測し,

I。を監視する。

2）I o が闇值以上になると，事故情報（地絡発生，位 相差 $\left.\theta_{2}\right)$ を子局に伝送する。

3) 配電用変電所の地絡方向継電器のトリップによる遮 断器の開放で事故停電となる。

4) 子局はバッテリー運転（９０秒）状態となり事故情 報をメモリーする。

$5 ）$ 変電所子局は停電中の子局からの情報 $\left(\theta_{2}\right)$ と $64 \phi に よ る$ 地絡相を中央装置に伝送する。

6) 中央装置では $\theta_{2}$ と64 фによる地絡相情報から地 絡方向判定し，事故区間の限定と自動融通を行う。

事故区間の限定は，従来からの時限順送による事故判定 区間と短絡・地絡方向のモニタリング情報に基づく事故判 定区間とのAND条件により実施している。図18にモ二 タリング情報による事故区間限定例を示す。 


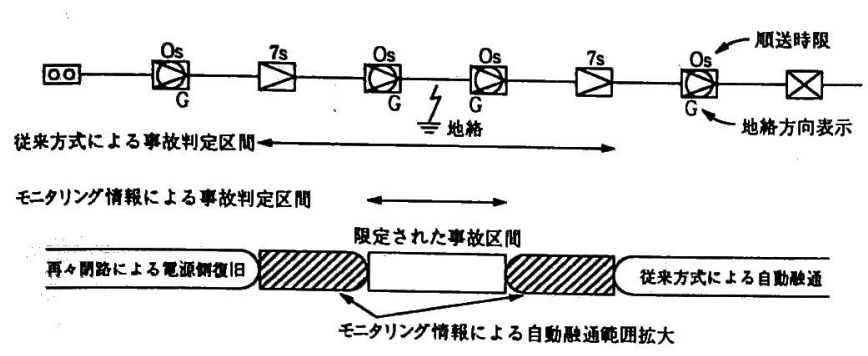

図 18 モニタリング情報による事故区間限定例

Fig. 18. Example of failure section isolation using monitoring information.

従来は順送時限 $(7 \mathrm{n}$ 秒) を有する開閉器で区分される 区間単位に自動融通範囲が制限され，8区間超過時には区 間中に手動開閉器を施設していた。

しかし，区間中の手動開閉器をモニタリング機能付きの 自動開閉器（8区間超過のため投入時限は 0 秒設定）に取 り替えることで， $7 \mathrm{n}$ 秒設定開閉器投入之瞬時に 0 秒設定 開閉器が投人することになる。このため, 再閉路継電方式 での 8 区間頭打ちの条件を変更することなく，実質的に倍 区間確保が可能となった。

これにより, 自動融通範囲が拡大し，事故区間縮小化に よる事故復旧時間の大幅な短縮が可能となった。

電流センサから中央装置までのシステム全体の総合試験 は, 電力中央研究所赤城試験センターの模擬配電線での事 故発生を関西電力の営業所の中央装置に情報伝送する形態 で実施し，事故区間の検出・判定から自動融通に至る一連 の処理が中央装置で確実に実施できることを確認できた。

\section{6. おわりに}

本報告ては, 配電線運転状態モニタリングシステムの開 発について希士類鉄ガーネット結晶を使用した配電線運転 状態モニタリング・センサの開発結果を踏まえて，一層の 事故停電時間短縮が達成でき, かつ既設の配電線自動運用 システムと融合できるシステムを提案した。

特に，地絡事故の検出および処理について新しい方式を 見いだすことができ，この部分を中心に報告した。

本システムは, 関西電力の営業所において順次導入を実 施し, 現地での検出例も報告(8) されており、今後より一 層の事故停電時間短縮に寄与するものと思われる。

報告した技術か配電線自動運用システムの高度化等につ ながれば幸甚である。おわりに，本研究に協力頂いた開閉 器子局と中央装置のメーカおよび実験に協力頂いた電力中 央研究所の関係者の方々に謝意を表します。

（平成 7 年 2 月 28 日受付, 同 7 年 6 月 15 日再受付)

\section{文献}

（1）関根泰次監修：「配電技術総合マニュアル」， (1) 99 9 1 年) オーム社

（2）不動：「関西電力における配電総合自動化システム」, 電気評論（1992 年 10 月号）第 77 巻第 10 号

（3）和田・不動・江川・石塚・石河 - 伊藤：「光方式電 流センサ用希士類鉄ガーネット結晶」, 電学論 C, $112 ， 793 \sim 797$ (平 $4-12$ )

（4）和田・不動・松田・石塚・福井：「配電線運転状態 モニタリングセンサの開発」，平 3 電気学会産業応 用部門全国大会

（5）和田・不動・江川・阿部・松村：「配電線運転状態 モニタリングセンサの開発」, 平 5 電気学会電力・ エネルギー部門大会, No299

（6）不動・和田・江川・石河・戸田：「配電線運転状態 モニタリング改良型センサの開発」，平 4 電気学会 ・電力技術研究会, PE-92-21

（7）和田・不動・朝倉・林・岸田・神馬：「配電線搬送 方式事故探査子局の開発」, 平 5 電気学会電力. エネルギー部門大会, No328

（8）水谷·川崎·安宅・阿部・松村·清水:「配電線用 光センサの現地検出例について」, 平 6 電気学会全 国大会, Nol 1393

不動 弘幸 （正員)1947年11月15日生まれ。66年 3 月 兵庫県立洲本実業高校電気科卒業。同年 関西電力侏入社。71 73年京都大学電気 工学科聴講生。主として, 配電線運用の 高度化関係の研究に従事。現在, 同社総 合技術研究所主任研究員。 元年度才一厶技術賞受賞。

平成 6 年度電気学会論文賞受賞。

川崎 幸男 （正員)1960年 1 月 3 日生まれ。 82 年 3 月 京都大学電気工学科卒業。同年関西電力 保人社。主として, 配電自動化関倸の システム開発に従事。現在，同社お客さ ま本部ネットワーク技術グループ副長。

江川 進

（正員）1960年 6 月10日生まれ。81年 3 月 和歌山高専電気工学科卒業。同年関西電 力侏入社。現在, 同社お客さま本部ネッ トワーク技術グループにて配電自動化 システムの開発に従事。平成 6 年度電気 学会論文賞受賞。 
篠崎 孝一（正員)1956年10月17日生まれ。77年 3 月 明石高専電気工学科卒業。同年関西電力 㑣入社。現在, 同社総合技術研究所流通 設備研究室副主任研究員。主として, 配 電自動化関係の研究に従事。

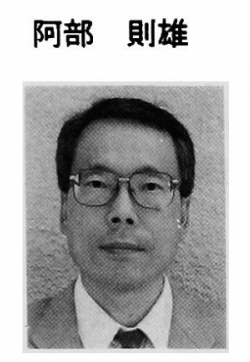

（正員）1950年 1 月 13 日生まれ。75年 3 月 京都大学工学部大学院修士課程終了。 同年住友電気工業㑣入社。主として，ヶ ーブルおよびセンサの研究に従事。現在, 同社電力機器部主席。

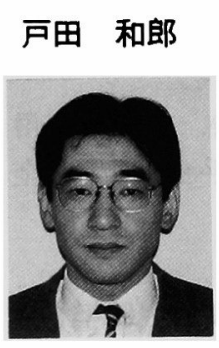

(非会員)1959年1月16日生まれ。82年3月 筑波大学基礎工学類卒業。同年松下電器 産業保入社。主として, 光センサの開発 に従事。現在, 同社ネットワーク開発推 進グループ主任技師。 